\title{
藍藻類の増殖抑制効果に対する曝気循環対策の 施設規模の影響 STUDY OF FACILITY SCALE FOR PREVENTION OF WATER BLOOM BY ARTIFICIAL CIRCULATION
}

\author{
後藤 浩一 1 ・古里 栄一 2 ・浅枝 隆 3 \\ Kouichi GOTOU, Eiichi FURUSATO and Takashi ASAEDA \\ 1正会員 独立行政法人水資源機構 総合技術推進室（テ338-0812 さいたま市桜区大字神田936） \\ 2正会員 埼玉大学大学院 理工学研究科（テ338-0825 さいたま市さくら区下大久保255） \\ 3 正会員 工博 埼玉大学大学院教授 理工学研究科（†338-0825 さいたま市さくら区下大久保255)
}

\begin{abstract}
We investigated the relationship between the abundance of cyanobacteria and stratification intensity $\left(N^{2}\right)$ in three eutrophicated reservoirs in which an artificial circulation system had been installed and the effects of the facility scale on that relationship. Cyanobacteria markedly increased when $N^{2}$ was above $10^{-}$ ${ }^{4}\left[\mathrm{~s}^{-2}\right]$ in all three reservoirs whether the artificial circulation was installed or not. A certain facility scale wais needed for the decrease of $N^{2}$. Sufficient decrease in $N^{2}$ by the facility occurred in the reservoir in which cyanobacteria was prevented. The appropriate facility scale to decrease $N^{2}$ was considered to be related to the internal Froude number inherent in each reservoir.
\end{abstract}

Key Words: artificial circulation, cyanobacterial bloom, stratification intensity, facility scale

\section{1. はじめに}

富栄養化したダム貯水池における藍藻類の異常発生の 抑制対策として，圧縮空気を貯水池の深部から放出して 貯水池の水温成層を制御する曝気循環対策 ${ }^{1)}$ が多くのダ ムで適用されている2),3). しかしながら，全ての場合にお いて藍藻類の増殖抑制が達成されているわけではない, ${ }^{4,5}$. この原因の一つとしては，曝気循環対策による効果の発 現機構が複雑であるために，合理的な設計・管理指針が 明らかになっていないことが考えられる。

曝気循環対策は，気泡噴流によって生じた密度流で貯 水池全域の水理環境を制御することによって，間接的に 植物プランクトンの生育環境を変化させて藍藻類の増殖 を抑制する手法である。水質障害を引き起こす Microcystis属やPhorimidium属は，競合戦略において安定 した成層を要求するといら性質が数多く指摘されている 5,6,7,8). そうした観点からの曝気循環対策による対策効果 も報告されている ${ }^{5), 9)}$. したがって, 藍藻類が増殖しにく い成層強度の低下を達成するという観点からの, 計画論 および管理論の構築が考えられる.このためには，曝気 循環装置の施設規模と, 水理学的過程を通じた生態学的 現象との因果関係を定量的に明らかにする必要がある.
こうした目的のためには様々な検討・実験手法が有効 であろうが，現地データより経験的な関係性を見いだす ことも有効であると考えられる．梅田ら ${ }^{5}$ は，富栄養化 した貯水池において藍藻類の増殖を抑制することが可能 な成層強度について現地データを用いて検討を行ってい るが，施設規模との関係については課題が残る. 本研究 においては，曝気循環装置の設置された複数のダム貯水 池における現地データを用いて，成層強度と藍藻類の現 存量の関係について検討するとともに，曝気循環装置に よる成層強度への影響を検討し, 藍藻類の増殖抑制を達 成することのできる曝気循環装置の施設規模に関する考 察を行うものである

\section{2. 対象データの概要}

\section{（1）ダム貯水池}

検討対象としたダム貯水池は，水資源機構所管ダムの 中で藍藻類の増殖に伴う水質障害の抑制を目的として散 気方式の曝気循環装置が設置されている 3 ダムとした (表-1). 群馬県に位置するKSダムは，流域面積 $254 \mathrm{~km}^{2}$, 堤高 $140 \mathrm{~m}$, 堤頂長 $405 \mathrm{~m}$, 総貯水容量 $60,500,000 \mathrm{~m}^{3}$ の重 力式コンクリートダムである. KSダム貯水池において 
表-1＼cjkstart検討対象ダムにおける曝気循環装置の適用状況および施設規模

\begin{tabular}{|c|c|c|c|c|}
\hline ダム名称 & 導入時期および基数 & 曝気循環施設 & $\begin{array}{c}\text { 湛水面積 } \\
\left(\mathrm{km}^{2}\right)^{\mathrm{a}} \\
\end{array}$ & $\begin{array}{c}\text { 施設規模 } \\
(k \text { 值 })^{\mathrm{b}} \\
\end{array}$ \\
\hline KSSダム & $\begin{array}{l}\text { 1994年 1基, 1995年 1基, 1996年 2基, 1997年 1基 } \\
\end{array}$ & 2 2400NL/min. $\times 5$ 基 & 1.26 & 195 \\
\hline TKダム & 2001年 1 基, 2003 年 1 基, 2004年 2 基 & $5600 \mathrm{NL} / \mathrm{min} . \times 4$ 基 & 1.4 & 214 \\
\hline TRダム ${ }^{\mathrm{c}}$ & 1999年 1基, 2003年 1基 & $3700 \mathrm{NL} / \mathrm{min} . \times 2$ 基 & 0.59 & 203 \\
\hline
\end{tabular}

夏季の湛水面積として，KSおよびTKダムは洪水期制限水位を，TRダムは常時満水位時の湛水面積を用いた。.

b各ダムにおいて曝気循環装置は段階的に導入されたが，ここでは全基導入後の施設規模を示した。

CTRダムにおいては，1995〜1997年の3力年は，同規模 1 基の施設が実験的に1〜2ケ月稼㗢していた.
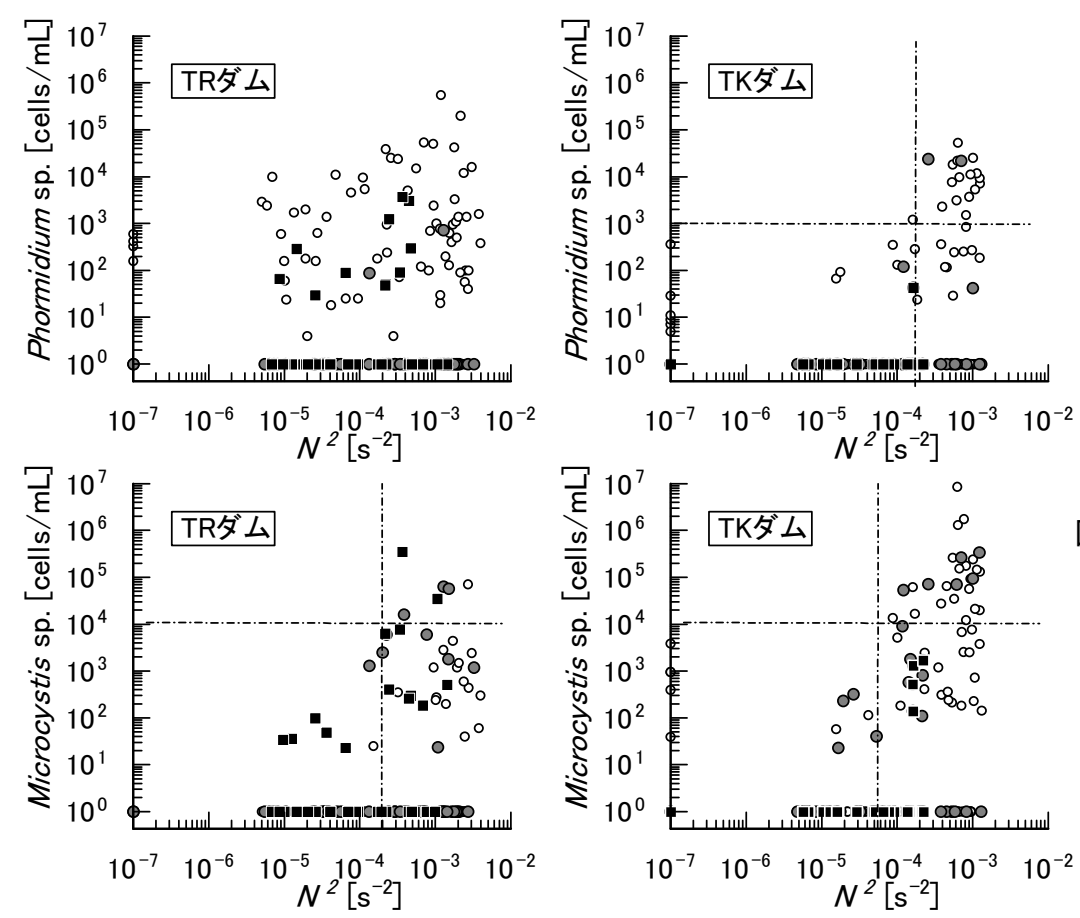

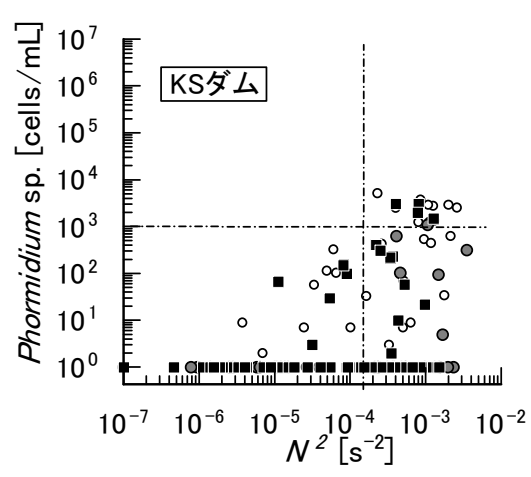

図-1＼cjkstart各ダム貯水池における成層強度と藍 藻類現存量との関係 $(\mathrm{O}$, 曝気循環施設 導入前; $\bigcirc$, 段階導入中 ; $\boldsymbol{\square}$, 全基導入 後 ; KSダムにおいてはMicrocystisは 出現していないために省略した．対象藍 藻類が確認されなかったデータは, $10^{0}[\mathrm{cel} / \mathrm{s} / \mathrm{mL}]$, 水温差が無い場合の $N^{2}$ は $10^{-7}\left[\mathrm{~s}^{-2}\right]$ として表示した. )
はPhormidium属によって生産された2-MIBによる異臭味 障害が発生していた。京都府に位置するTKダムは, 流域面積 $615 \mathrm{~km}^{2}$, 堤高 $67 \mathrm{~m}$, 堤頂長 $208.7 \mathrm{~m}$, 総貯水容量 $56,800,000 \mathrm{~m}^{3}$ のアーチダムである。TRダムは，福岡県に 位置する流域面積 $51 \mathrm{~km}^{2}$, 堤高 $83 \mathrm{~m}$, 堤頂長 $420 \mathrm{~m}$, 総貯 水容量 $18,000,000 \mathrm{~m}^{3}$ のロックフィルダムである. TKダム およびTRダムの両貯水池においては，KSダム貯水池と 同じくPhormidium属の増殖に加えて, 主にMicrocystis属 によって発生したアオコによる景観障害が発生していた。

\section{(2) 使用データ}

\section{a) 対象期間}

研究で用いたデータの対象期間は，曝気循環装置の設 置時期(表-1)を考慮し, 各ダムにおいて装置導入前後が 数年以上含まれることを図り，KSダムと TRダムについ ては1989年から1995年までの17カ年, TKダムについて は1991年から1995年までの15力年とした。

\section{b) 藍藻類の現存量と成層強度}

藍藻類の現存量は，ダムサイト付近の基準地点におい て月 1 回の頻度で実施されている定期調査結果における
植物プランクトンデータより, 表層のMicrocystis属およ びPhormidium属の細胞数を用いた。成層強度の指標は, 既存研究5),9) と同様に，角周波数である浮力周波数 $(N)$ を

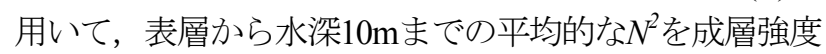
として用いた(式1).

$$
N^{2}=\frac{g}{\rho_{0}} \frac{\rho_{z}-\rho_{s}}{\Delta z}
$$

ここで， $g$, 重力加速度; $\rho_{0}$, 基準密度（本論文では $1.0 \times 10^{3}\left[\mathrm{~kg} / \mathrm{m}^{3}\right]$ とした）； $\rho_{z}$, 水深 $\mathrm{Z}$ の密度; $\rho_{s}$, 表層密 度, $\Delta z$, 表層と水深 $z$ の層厚である. 密度は, 植物プラ ンクトンサンプルの採水時に同地点で機器測定された水 温鉛直分布データより算定した. 算出水深は各貯水池に おける水温鉛直分布の状況と藍藻類の増殖環境という観 点より表層から水深 $10 \mathrm{~m}$ とた。

\section{c）曝気循環施設の規模と成層期平均成層強度}

曝気循環施設の規模を指標する数值として, 貯水池規 模と循環流量の規模との比率を考慮した $k$ 值 ${ }^{11)}$ を用いた (表-1).

$$
k=\sum \sqrt{Q_{B}} / A
$$


ここで， $Q_{B}$, 曝気循環装置 1 基あたりの吐出空気量 [L/min.]; $A$, 湛水面積 $\left[\mathrm{km}^{2}\right]$ である. $k$ 值が大きいほど，貯 水池規模に対して曝気循環装置による循環混合の影響が 大きくなる．湛水面積は，藍藻類の増殖時期である夏季 の湛水面積として，オールサーチャージ方式のTRダム においては常時満水位を, 制限水位方式のKSダムおよ びTKダムにおいては洪水期制限水位を用いた。

本研究において曝気循環施設の規模と成層強度との関 係を検討するためには，各ダムの曝気循環施設の規模と 対応する成層強度を定める必要がある，当該対策は，植 物プランクトンの増殖が活発な成層期における成層強度 を低下させることから, 成層期平均成層強度 $\left(N^{2}{ }_{s t}\right)$ を, 式(1)で得られた各月の成層強度の単純平均から定めた. したがって， 1 年毎の $N^{2}{ }_{s t}$ の值が存在する，なお，成層 期としては4月から10月までと仮定した.

\section{3. 現地データにおける成層強度と藍藻類現存量}

\section{および曝気循環対策の関係}

\section{（1）各ダムにおける成層強度と藍藻類現存量との関係}

図-1に，各貯水池における成層強度とPhorimidium属 およびMicrocystis属の細胞数との関係を示す．なお，各 藍藻類の細胞数が検出されなかったデータは $10^{0}[\mathrm{cell} / \mathrm{s} / \mathrm{mL}]$ として表示し，表層と水深 $10 \mathrm{~m}$ の水温が全 く同一である場合には $N^{2} は 10^{-7}[\mathrm{~s}-2]$ として図では表示し た. 各データにおいて，成層強度が増加するほど当該成 層強度条件における藍藻類現存量が多くなる傾向がある こうした関係は，既往研究においても複数のダム貯水池 で確認されている ${ }^{5), 9)}$. 藍藻類が水質障害を生じるレベル の現存量に達する $N^{2}$ 定めるために，図中には一般的な アオコ発生レベルとされる現存量(Microcystis 属 : $10^{4} \mathrm{cells} / \mathrm{mL}^{10)}$ と，これを上回ることの無い $N^{2}$ の境界線を 示した。なお，梅田ら ${ }^{5)}$ と同様にPhorimidium 属は $10^{3}$ cells $/ \mathrm{mL}$ を水質障害レベルとして図示した。TRダムに おけるPhormidium属を除いては，約 $10^{-4}\left[\mathrm{~s}^{-2}\right]$ を下回る $N^{2}$ 条件ではこれらの藍藻類は水質障害を引き起こす現存量 レベル以上に増殖していない. 本研究で対象とした複数 のダム貯水池では共通して約 $10^{-4}\left[\mathrm{~s}^{-2}\right]$ の $N^{2} レ$ ベルが藍藻 類が顕著に増殖するか否かの境界となる条件であると考 えられる．梅田ら ${ }^{9)}$ も複数のダ $ム$ 貯水池において， $N^{2}$ 評 価水深を等しくした場合は，藍藻類の出現限界となる $N^{2}$ がほぼ同レベルの值であることを報告している．異なっ たダム間において成層強度と藍藻類の現存量との関係が ほぼ共通していたことは，安定成層要求性の強い藍藻類 の動態に対する成層強度の影響の強さを示すものである と考えられる.
低い $N^{2}$ 条件においてもPhormidium属の現存量がTRダ ムで多かった理由としては，混合状態に対して異なった 応答特性を有する生態特性のタイプがTRダムでは存在 していたことが推定される．例えば $10^{-5}\left[\mathrm{~s}^{-2}\right]$ という低い $N^{2}$ 条件においてさえ，Phormidium属細胞数が $10^{4}[\mathrm{cells} / \mathrm{mL}]$ に達するデータが存在している．掲載は省略するが，こ れらは冬季を中心とした循環期のデータである.

Phorimidium属には主要なアンテナ色素の違いに応じて PC-type とPE-typeが存在する. 水中で比較的透過性の良 い短波長光を吸収するPE-typeは，混合環境で出現する 傾向がある ${ }^{8), 9)}$. TRダムにおいては色素タイプ別に Phorimidium属細胞数が計測されていなかったために断 言はできないが，低い $N^{2}$ 条件の循環期においても Phorimidium属細胞数が水質障害レベルに達していたの は，PE-typeが主体であったことが原因である可能性が ある。

\section{（2）曝気循環による成層強度と藍藻類への影響}

前述した成層強度と藍藻類現存量との関係は, 曝気循 環装置の設置前後で顕著な違いは無かった(図-1). KSダ ムとTRダムにおいては，全基導入後も TKダムほど成層 強度は低くなっておらず，藍藻類現存量も多い状態が継 続していた. 一方TKダムにおいては，2003年に曝気循 環装置が4基に増設された以降は，それ以前に比べて成 層強度が低下して $10^{-4}\left[\mathrm{~s}^{-2}\right]$ を超過することが少なくなって おり，藍藻類の増殖は対策によって抑制された。

各ダムにおける，対策による藍藻類抑制効果の違いは， 曝気循環対策による成層強度への影響がダムに応じて異 なっていたためである考えられる. 藍藻類の増殖抑制を 達成したTKダムにおいては, 藍藻類が増殖しにくいレ ベルの成層強度まで循環混合された。これに対してKS ダムおよびTRダムにおいては, 曝気循環装置によって 成層強度は低下したが藍藻類が増殖困難なレベルにまで 成層強度を低下できなかったことから，対策後において も藍藻類が増殖していると考えられる. 以上より, 曝気 循環装置による藍藻類増殖抑制のためには, 単に水理状 態に何らかの影響を及ぼすだけではなく，成層強度を藍 藻類の増殖に適さないレベルにまで低下させる必要があ ると言えよう。

ただし, TRダムのPhorimidium属については, 対策後 は成層強度条件に関わらず現存量が減少したために，対 策による成層強度への影響を通じた現存量の変動は確認 できなかった。掲載は省略したが，対策導入とほぼ同時 期から藍藻類の優占種がMicrocystis属に変化している. 成層状態以外の他の環境要素あるいは植物プランクトン 群集そのものの遷移によってPhormidium属が減少したと 考えられる. 


\section{4. 藍藻類の増殖抑制可能な施設規模の検討}

\section{（1）曝気循環装置の施設規模と成層強度との関係}

表-1に検討対象ダムにおける曝気循環施設の施設規模 を比較して示す．いずれのダムにおいても全基導入後の $k$ 值は200前後であり顕著な違いは無い.だが，ダム貯水 池に応じて藍藻類の増殖抑制効果が異なっていた. この 原因として，ダム毎に曝気循環対策による水温成層の制 御効果が異なる可能性が考えられる，そこで，各ダムに おける対策の施設規模と成層強度の変化を検討した.

図-2に，各ダム貯水池における $k$ 值と成層期平均成層 強度 $\left(N^{2}{ }_{s t}\right)$ との関係を示す。なお， $N^{2}{ }_{s t}$ は年次毎にデー タが存在することから，図では当該 $k$ 值の設備導入状況 における複数年の平均值と標準偏差を示した. 各ダムに おいて曝気循環装置は段階的に導入されたため, それぞ れ複数の $k$ 值の状況におけるデータが存在する. また $k$ 值が 0 である場合は曝気循環施設が存在しないことを意 味している.

$k$ 值が100未満の条件では，いずれの貯水池においても $k$ 值の増加に応じた $N^{2}{ }_{s t}$ の顕著な変化は見られない。 こ れは，曝気循環施設の規模が十分で無い場合には，混合 作用が生じたとしても成層強度の低下には至らないため であると考えられる。一方 $k$ 值が200程度であれば各ダム における $N^{2}{ }_{s t}$ は低下している，成層強度の低下のために は一定の規模の曝気循環施設が必要であると考えられる. ただし， $k$ 值が約200の条件における $N^{2}{ }_{s t}$ の絶対值は，ダ ムによって異なっている. 曝気循環装置導入後も藍藻類 が増殖しているKSダムとTRダムにおいては， $k$ 值200程 度において $N^{2}{ }_{s t}$ は低下しているものの，TKダムの無対 策時と同レベルの $N^{2}{ }_{s t}$ である. 図よりわかる様に，この 要因としては，KSダムとTRダムとでは $k$ 值が 0 の条件, すなわち無対策時における $N^{2}{ }_{s t}$ が高い性質が考えられる。 曝気循環対策の目的は，水質障害を引き起こす藍藻類 の増殖抑制であり，貯水池水理環境の制御は一手段に過 ぎない，したがって，定性的な評価としてはKSダムお よびTRダムにおいては曝気循環装置による物理的な影 響としての混合化は発揮されているが，藍藻類増殖抑制 のためには混合効果が不十分であると考えられる。この 要因としては, ダム固有の成層の強さに応じて曝気循環 装置に求められる成層強度の低下幅が異なることが考え られる。したがって，曝気循環施設の適正施設規模を検 討するためには，無対策時の成層強度が重要となる.

\section{（2）無対策時の成層強度 $\left(N^{2}{ }_{s t-0}\right)$ に関する考察}

上記の検討によって，必要な施設規模のダムによる違

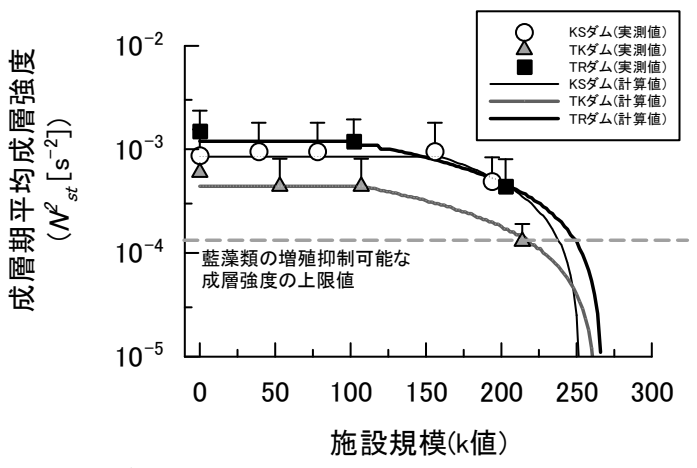

図-2 各ダムにおける曝気循環装置の施設規模 $(k)$ と成層期 平均成層強度 $\left(N_{s t}^{*}\right)$ との関係（計算值は式 (4) のうち線形 式による近似線である. )

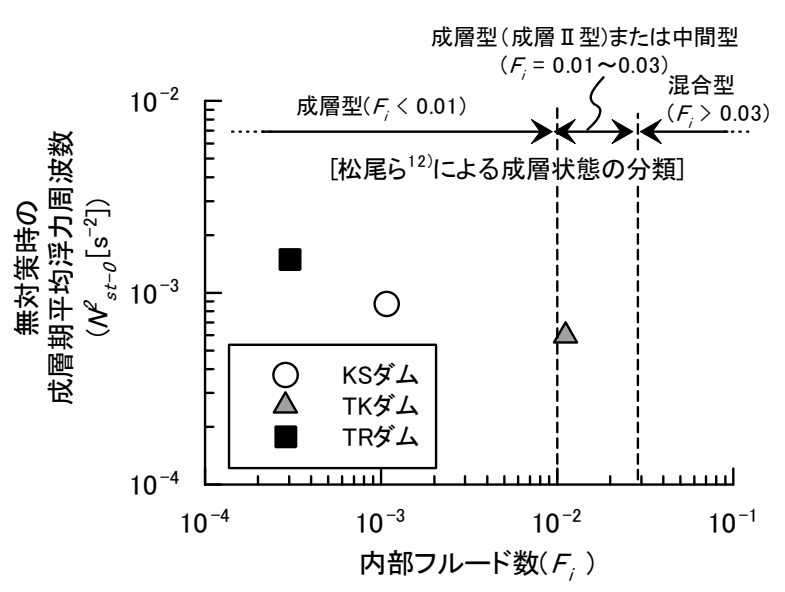

図-3 各ダムにおける $F_{i}$ と $N^{2}{ }_{s t-0}$ との関係

いに対して無対策時の成層強度 $\left(N^{2}{ }_{s t-0}\right)$ が影響している 可能性があると考えられた。一般的に，ダム貯水池にお ける水温成層に影響を与える因子として気象や流況等が ある．掲載は省略するが，検討を行った 3 ダムにおいて 日射量や気温，流入量や風速データの統計值を整理した 結果，流入量が少ないダムほど $N^{2}{ }_{s t-0}$ が大きい傾向が あった. ダム貯水池における成層形成の有無の判定指標 として，内部フルード数 $\left(F_{i}\right)$ がある ${ }^{12)}$. 本研究において も，流入量による成層への影響は貯水地形状を加味した 流速スケールとして生じると考え，流入に関する混合の 指標として流速スケールを考慮した $F_{i}$ を算定した。

$$
F_{i}=\frac{U}{\sqrt{g^{\prime} \cdot H}}
$$

ここで， $U$; 流速スケール， $g^{\prime}$; 成層の密度差で補正 した重力加速度, $H$; 水深である. $U$ は成層期平均流 入量を貯水池平均横断面積で除した值を, $g^{\prime}$ は $N^{2}{ }_{s t-0}$ を 用いた值を，Hは成層強度の算定水深である $10 \mathrm{~m}$ 用い た. 図-3に，対象 3 ダムにおける $N_{s t-0}^{2}$ と， $F_{i}$ との関係 を示す． $F_{i}$ が大きいほど，成層時の浮力に対する慣性力 
表-2ＫSダムとTRダムにおける適性施設規模の検討数値

\begin{tabular}{ccc}
\hline 記号 & KSダム & TRダム \\
\hline \hline$N^{2}{ }_{s t-0}$ & $8.5 \times 10^{-4}$ & $1.2 \times 10^{-3}$ \\
$f(k)$ & $-9.1 \times 10^{-6} \times k$ & $-7.1 \times 10^{-6} \times k$ \\
& $-1.6 \times 10^{-3} \times \ln (k)$ & $-1.05 \times 10^{-3} \times \ln (k)$ \\
\hline$N^{2}{ }_{s t-k 0}{ }^{a}$ & $2.3 \times 10^{-4}$ & $1.9 \times 10^{-3}$ \\
$k_{t h}{ }^{a}$ & $8.9 \times 10^{-3}$ & $6.0 \times 10^{-3}$ \\
$k r e q$ & 156 & 102 \\
\hline
\end{tabular}

${ }^{\mathrm{a}}$ 欄内の上側は線形近似，下側は対数近似の式や值を示した

の影響が大きくなる．松尾ら ${ }^{12)}$ は，0.01以下で成層型 0.03 以上で混合型となることを報告しており，対象の3 ダムは成層型に相当する. 図よりわかる様に，複数ダム 間において $F_{i}$ が大きいほど $N^{2}{ }_{s t-0}$ が小さくなる傾向があ

る。つまり，曝気循環対策を実施していない状況にお ける成層強度に対して， $F_{i}$ で指標される水理要素が影響 を与えている可能性がある事を示していると考えられる. 本検討では3ダムの值のみに基づいていることから，図3の関係性については多くのデータによる検証が必要で あるが，同様の施設規模( $k$ 值)の曝気循環装置が導入され ているにもかかわらず藍藻類抑制効果および水温成層の 制御状況がダムによって異なったことについては，F $F_{i}$ で 指標されるダム固有の成層のしやすさの違いが影響して いることが推察される。

\section{（3）藍藻類の増殖抑制に必要な施設規模の検討}

以上の検討に基づいて，KSダムおよびTRダムにおい て藍藻類の増殖抑制を達成するための施設規模の検討を 試みた，検討にあたっては，これら両ダムの成層強度を， TKダムにおける $k$ 值200強でのレベルにまで低下させる ための $k$ 值を試算することとした．水温成層の曝気循環 に対する応答性については数值解析モデルによる詳細な 検討が必要であろらが，ここでは図-2に示した $k$ 值と $N^{2}{ }_{s t}$ との関係から近似モデルを作成し，検討することと した。この近似モデルを式Aに示す．前述した様に，適 正施設規模の検討にあたっては無対策時におけるダム固 有の成層強度の定義が必要となるが，KSダムおよびTR ダムにおいては既に図-3に示した無対策時の成層強度值 が得られていることから実測值を用いることとした。

$$
N_{s t}^{2}=\left|\begin{array}{lll}
N_{s t-0}^{2} & \text { if: } & k \\
f(k)+N^{2}{ }_{s t-k 0} & &
\end{array}\right| \begin{aligned}
& <k_{t h} \\
& \geq k_{t h}
\end{aligned}
$$

ここで, $N_{s t}^{2}$, 成層期平均成層強度 $\left[\mathrm{s}^{-2}\right] ; N^{2}{ }_{s t-0}$, 曝気循 環を実施しない場合 $(k=0)$ の成層期平均成層強度 $\left[\mathrm{s}^{-2}\right] ; f(k)$, $k$ 值の増大に応じた $N^{2}{ }_{s t}$ の低下幅に関する関数 $\left[\mathrm{s}^{-2}\right] ; k_{t h}$, 曝気循環によって成層強度が低下寸る境界となる $k$ 值で ある. $N_{s t-0}^{2}$ は， $\mathrm{k}$ 值が約 100 以下の条件における $N^{2}{ }_{s t}$ の 平均より定めた. $k_{t h}$, は式(4)の2つの式の交点に相当する k值として定めた. $f(k)$ については様々な関数形の近似 を行った結果，線形 $(f(k)=a k)$ および対数形 $(f(k)=a \ln (k))$ の相関が高かったためにこれら両近似関 数を用いた. 表-2にKSダムおよびTRダムの各種数值と, これらより得られた望ましい $k$ 值(kreq)を示した。また， 図-2には表-2に基づく近似線のうち，線形式による近似 線を示した. kreqはKSダムとTRダムにおいてTKダムと 同様の $N^{2}{ }_{s t}$ を達成可能であり，藍藻類の増殖抑制が期待 できるk值である.

表-2に示した様に，両ダムにおいて藍藻類増殖抑制に 必要な施設規模は， $k$ 值にして250前後であると推測され た. なお， $k_{t h}$ の小さいKSダムの方がTRダムに比べて kreqが大きい理由は，KSダムの方が， $f(k)$ の係数の絶 対值が大きく, $k$ 值の増加に対する $N^{2}{ }_{s t}$ の低減が大きい ためである. 両ダムのkreqは現状施設よりもk值として $\mathrm{KS}$ ダムでは約45，TRダムでは約60弱の増加に相当する. これは，実際の施設としては，いずれのダムにおいても 現状の導入施設を1基増加させれば達成できる $k$ 值である. この様な簡易な方法によって曝気循環対策の適正施設規 模に関する目安を得ることが可能ならば，有用性が高い と考えられる.

ただし，本研究成果に基づいてただちに増設を実施す ることは，いくつかの問題点や課題が現時点では存在す ることから，適切ではない. 図-2に示した近似線は，数 条件のみの $k$ 值のデータから得た経験式に基づくもので ある.より多くの $k$ 值のデータが存在すれば，近似線は 変化する可能性がある. 200 以上の $k$ 值条件に外挿して推 測したkreqの值は，精度や確実性の面で問題がある. 200 以上の $\mathrm{k}$ 值に相当するダム貯水池の実測值の解析や, 数值解析モデルによる $k$ 值の増加に対する $N^{2}{ }_{s t}$ の応答性 の解析を行うことによって，こうした課題は解決できる と考えられる。 また，ダムに応じて $k$ 值と $N^{2}{ }_{s t}$ との関係 が異なる事も推測されるので，多くのダムのデータを用 いた $k$ 值による $N^{2}{ }_{s t}$ への影響の検討も必要であろう。

\section{5. 課題}

本研究では3ダムのデータのみを用いたために，研究 成果の汎用性については問題が残る.この解決のために は，多くのダム貯水池のデータを対象に同様な検討を行 う必要がある。ささらに，本論文で提案した方法において は，成層強度の指標である $N^{2} か ゙$ 極めて重要な意味を持っ ている. 本研究では複数ダム貯水池の実測值に基づいて, 約 $10^{-4}\left[\mathrm{~s}^{-2}\right] の N^{2}$ が，藍藻類の生育における境界值となるこ とを示したが，これは経験的な結果でしかない. この ${ }^{2}$ の值は水温 $20^{\circ} \mathrm{C}$ 以では水深 $1 \mathrm{~m}$ 上たり゙おおむ䄪 
$0.1^{\circ} \mathrm{C}$ 水温勾配に相当する值である。この条件が，ど ういった強度や頻度の循環状態に相当するのかという水 理学的な意味に加えて, 植物プランクトンの動態に対し てどういう過程を経て影響するかを明らかにする必要が ある。また，成層強度の評価条件についても，藍藻類の 生育環境の指標として適切な条件として，評価水深，測 定時間，植物プランクトン調査とのタイムラグ等につい て検討する必要があろう。

本研究では藍藻類の生育環境要素として物理条件であ る $N^{2}$ にの着目したが, 水温や日射量等の他の物理要素 や，栄養塩や $\mathrm{p} \mathrm{H}$ 等の化学的要素の影響も考慮する必要 がある. 特に, 適正な施設規模について本研究では成層 強度の観点から検討したが，日射量，栄養塩，回転率お よび水温等のダムによって条件の異なる要素によって適 正施設規模が影響を受ける可能性もある. 本研究で対象 とする事象は，曝気循環装置による物理過程や藍藻類の 動態にかかる生理生態学的過程に加え, ダム貯水池固有 の成層特性等広い範囲にわたる事から，こうした様々な 課題について明らかにする必要がある. これらの課題を 解決することにより, 現在多くのダムにおいて経験的に 適用されている曝気循環対策の費用対効果の最大化が可 能になると考えられる.

\section{6. 結論}

曝気循環施設の導入されているダム貯水池における実 測值を用いて, 藍藻類現存量と成層強度との関係および これに及ぼす施設規模の関係の検討を行った. 本論文の 結論は以下の通りである。

1) 水質障害を引き起こす現存量レベルに藍藻類が増殖

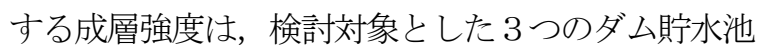
で共通して約 $10^{-4}\left[\mathrm{~s}^{-2}\right]$ 以上であり，曝気循環装置の導 入前後でこの傾向は変化しなかった.

2) 曝気循環対策によって藍藻類の増殖が抑制されたダ ムでは，成層強度が $10^{-4}\left[\mathrm{~s}^{-2}\right]$ 以下に低下していた。

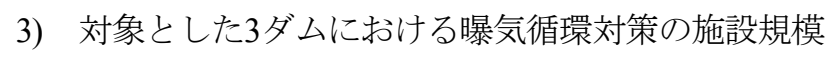
と夏季平均成層強度の関係は類似しており, 一定レ ベル以上の施設規模で成層強度の低下が生じた。

4) ダムによる藍藻類増殖抑制効果の違いは，ダム貯水 池固有の成層の強さが影響していると考えられた.

5) ダム貯水池それぞれに固有な成層強度は，気象や緯 度ではなく，内部フルード数で指標される条件に影 響を受けていると考えられた。

6) 対象3ダムの実測值から，曝気循環対策の施設規模 と成層強度の関係の経験式を提案した.

7) この経験式を用いてKSダムとTRダムにおいて，藍
藻類の増殖抑制を可能にする施設規模を推定した.

謝辞 : 本論文の3名の査読者から貴重なご意見を頂き, 論旨をより向上することができた：ここに記して謝意を 表する.

\section{参考文献}

1) 廣瀬敏雄, 丹羽薰, 久納誠, 山下芳裕 : 流動制御と糸状藻類 を活用したダム湖水環境創造システム, 大ダム, Vol. 153, pp72-82, 1995.

2) 荒井治, 高須修二: ダム湖の水質対策の動向, ダム工学, Vol. 7(2), pp90-97, 1997.

3) 寺川陽, 福渡隆: ダム湖の富栄養化対策の動向, ダム技術, No. 136, pp31-39, 1998.

4) 有馬慎一郎, 佐々木弘二, 福崎彰, 古里栄一, 浅枝隆 : 寺内 ダムにおける曝気循環装置による藍藻類増殖抑制対策に関す る考察 ( I : 曝気循環施設規模と藍藻類の抑制効果との関 係）, 土木学会第60回年次学術講演会, 7-068, pp135-136, 2005.

5) 梅田信, 古里栄一, 浅枝隆: 富栄養化したダム湖におけるア オコ発生指標としての水温成層安定性, ダム工学, Vol. 16(4), pp269-281, 2006.

6) Visser, M.P., Ibelings, W.B., Van der Veer, B., Koedood, J. and Mur, R.L.: Artificial mixing prevents nuisance blooms of the cyanobacterium Microcystis in Lake Nieuwe Meer, the Netherlands, Freshwater Biology, Vol. 36, pp.435-450, 1996.

7) Reynolds, C.S.: Vegetation processes in the pelagic: A model for ecosystem theory, 329pp, Ecology Institute, Oldendorf/Luhe, Germany, 1997.

8) 古里栄一, 浅枝隆, 須藤隆一 : アンテナ色素の吸光特性に基 づく藍藻類の光学的および水理学的発生条件に関する理論的 考察一減衰スペクトル特性と混合水深一, 水環境学会誌, Vol. 26, pp277-284, 2003.

9) 古里栄一, 浅枝隆, 須藤隆一 : アンテナ色素の吸光特性に基 づく藍藻類の光学的および水理学的発生条件に関する現地 データを用いた考察—アンテナ色素・浮力周波数仮説一, 水 環境学会誌, Vol.26, pp285-293, 2003.

10) 国土開発技術研究センター: 貯水池の生物, 142pp, 国土開 発技術研究センター, 東京, 1982 .

11) 丹羽薰・久納誠・久保徳彦・真田誠至 : 流動制御システム に関する実験, 土木研究所資料, 第3375号, pp.101-102, 1995.

12) 松尾直規・岩佐義朗・綾史朗 : 多目的貯水池の水温分布特 性とその影響要因, 第27回水理講演会論文集, 土木学会, pp.151-158, 1983.

13) 関根秀明, 吉田延雄, 梅田信, 浅枝隆 : 曝気式循環施設の 理論とその効果に関する考え方, ダム工学, vol. 13(1), 5-18, 2003.

(2007.9.30受付) 